Review Article

\title{
Geology of the Neoproterozoic - Early Cambrian Marwar Supergroup, Rajasthan: A Synthesis
}

\author{
BIVIN G GEORGE* \\ Geosciences Division, Physical Research Laboratory, Ahmedabad 380 009, India
}

(Received on 05 August 2017; Revised on 01 November 2018; Accepted on 16 August 2019)

\begin{abstract}
The Marwar Supergroup of the western India is one the largest Proterozoic sedimentary sequences of peninsular India. Due to its terminal Neoproterozoic- early Cambrian antiquity, these deposits are believed to hold potential clues to our understanding of the Proterozoic ocean, atmosphere, and origin of the complex multicellular life. Numerous paleobiological investigations in these largely fluvial and shallow marine deposits have brought out some intriguing results over the last decade. Similarly, chemostratigraphic studies have correlated the Bilara Group carbonates with Hanseran Group evaporites, and placed the middle and upper Marwar Supergroup alongside a host of late Ediacaran trans-Gondwanan basins. In this review, I have compiled the available lithostratigraphic, paleobiological, chemostratigraphic, and geochronological data from the Marwar Supergroup. In the wake of new age constraints for the Jodhpur Group, some of the trace fossil assemblages might require revisiting whereas new geochronologic data from within the supergroup would come in handy as we continue to look for the evidence of various Neoproterozoic global events in India.
\end{abstract}

Keywords: Neoproterozic, Western India, Chemostratigraphy, Provenance, Biostratigraphy

\section{Introduction}

The Marwar Supergroup, formerly known as the Trans-Aravalli Vindhyans (Heron, 1932), of NW India is one of the largest Proterozoic sedimentary successions of India. Spread across an area of over $100,000 \mathrm{~km}^{2}$ (Kumar, 1999), the supergroup consists of largely unmetamorphosed and undeformed fluvial and marginal marine siliciclastics, marine carbonates, and minor volcaniclastics, deposited in an intracratonic sag setting (Fig. 1; Chauhan et al., 2004). Sedimentation in the Marwar Basin initiated over the $\sim 750$ Ma Malani Igneous Suite (MIS) subsequent to the break-up of Rodinia (Roy and Jakhar, 2002; George and Ray, 2017), and continued up to the early Cambrian (McKenzie et al., 2011) making the sedimentary succession unique among the traditional PaleoNeoproterozoic 'Purana' basins of India (Fig. 2).

Owing to its continuity well into the Cambrian, the supergroup has been subject to a number of paleobiological investigations. Various evidence of biological activity in the form of microbially induced sedimentary structures (MISS; Sarkar et al., 2008; Kumar and Ahmad, 2014) and trace fossils of suspected Ediacaran fauna (Kumar and Pandey, 2009; Kumar and Ahmad, 2016; Pandey and Sharma, 2016) from the Neoproterozoic lower part of the Marwar Supergroup have reiterated the belief that this sedimentary sequence potentially hold clues to our understanding of the origin and evolution of the complex multicellular life. The paleomagnetic studies from within the Marwar Supergroup suggest an equatorial paleogeographic position for the Indian shield during the development of basin, alongside the Arabian-Nubian shield, Eastern Antarctica, and Australia in the Ediacaran-early Cambrian Period (Davis et al., 2014); whereas data from the basement Malani Igneous Suite (MIS) places it at intermediate northerly latitudes along with Laurentia, Baltica, South China, and Seychelles, that formed the western margin of the Rodinia (Gregory et al., 2009). Due to its temporal occurrence and spatial configuration, the sedimentary succession of the Marwar Basin is likely to encompass the history of evolution of the Indian

*Author for Correspondence: E-mail: bivin@prl.res.in 
shield during the late Neoproterozoic and early Cambrian; an era which has witnessed dynamic changes in climate, like the snowball Earth glaciations, (Hoffman et al., 1998; Och and Shields-Zhou, 2012), evolution of metazoans (Canfield et al., 2007; McFadden et al., 2008), and tectonics in terms of continental configurations (Meert, 2003; Collins and Pisarevsky, 2005). This review is a brief compilation and synthesis of the available lithostratigraphic, paleobiological, chemostratigraphic, and geochronological data from the Marwar Supergroup.

\section{Lithostratigraphy of the Marwar Supergroup}

The rocks of the Marwar Supergroup are exposed predominantly in the southern part of the basin (Fig. 1). A large part of the basin, mostly in the north and central regions, is buried under the Quaternary sand deposits of the Thar Desert where the stratigraphy is based on the available borehole data (Roy, 2001). The
Marwar Basin, also referred to as the NagaurGanganagar and Nagaur-Bikaner basins, is bounded by the Aravalli Mountain range, the Delhi-Lahore subsurface ridge and the Devikot-Nachna subsurface high in the east, north, and southwest, respectively (Pareek, 1984). The sedimentary succession unconformably overlies the MIS which forms the basement of the basin in the central and western regions (Fig. 3A). The outcrops of the Marwar Supergroup in the east, exposed near the Khatu village, are deposited over a sequence of highly deformed metasedimentary rocks which belong to the $\sim 850 \mathrm{Ma}$ old Sirohi Group (Paliwal, 1998). Erinpura Granite also forms the basement at places in the eastern fringe of the basin (Linnemann and Sharma, 2014).

The Marwar Supergroup has an estimated maximum thickness of $2000 \mathrm{~m}$ (Pareek, 1981) and is classified into three groups from bottom to top as: the Jodhpur Group, the Bilara Group, and the Nagaur

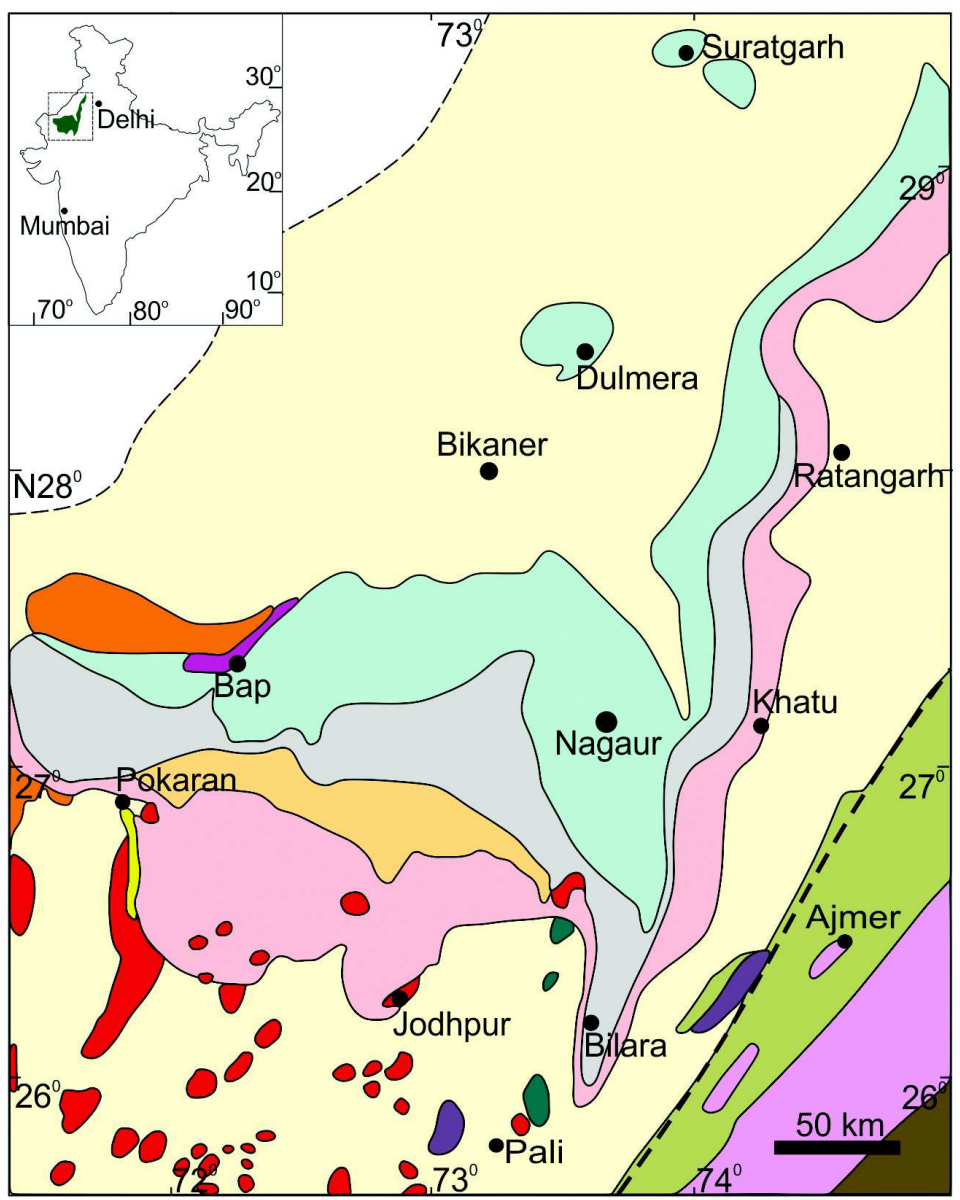

\begin{tabular}{|c|c|}
\hline Quaternary & \\
\hline Mesozoic & \\
\hline Bap Boulder Bed & \\
\hline Nagaur Group & \\
\hline Bilara Group & \\
\hline Girbhakar Formation & \\
\hline Sonia Formation & $\begin{array}{l}\text { Jodhpur } \\
\text { Group }\end{array}$ \\
\hline Pokaran Boulder Bed & \\
\hline Malani Igneous Suite & (MIS) \\
\hline Sirohi Group & \\
\hline Erinpura Granite & \\
\hline Delhi Supergroup & \\
\hline Aravalli Supergroup & \\
\hline $\begin{array}{l}\text { Banded Gneissic } \\
\text { Complex-II (BGC-II) }\end{array}$ & \\
\hline Faults & \\
\hline $\begin{array}{l}\text { International } \\
\text { boundary }\end{array}$ & \\
\hline
\end{tabular}

Fig. 1: Geological map of western India showing Marwar Supergroup with stratigraphic subdivisions and surrounding lithotectonic units (modified after Roy and Jakhar, 2002; Pareek, 1981) 
Group (Fig. 2). The unconformity between the MIS and the Marwar Supergroup is represented by the Pokaran Boulder Bed which is exposed

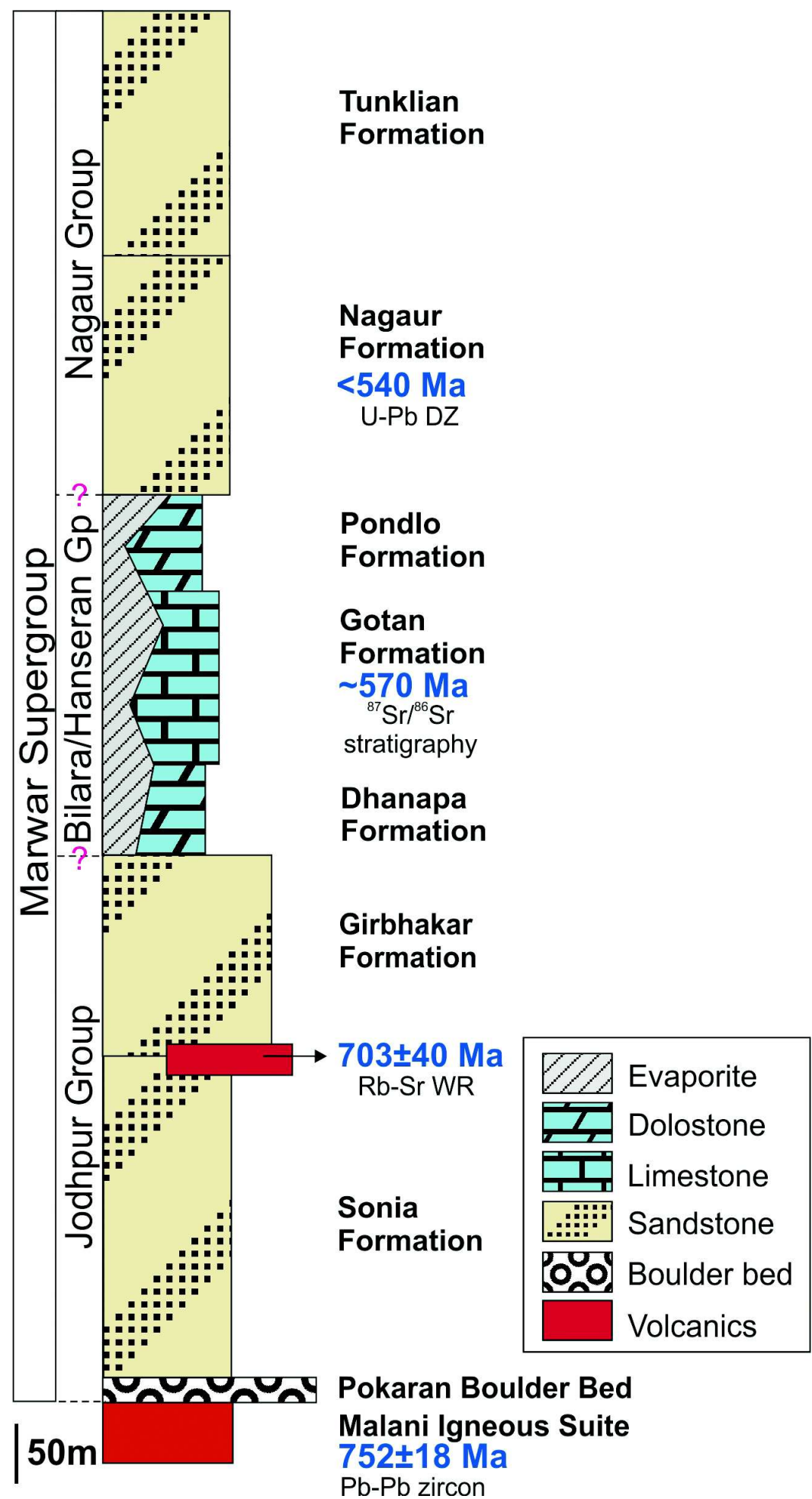

Fig. 2: Simplified stratigraphy of the Marwar Supergroup based on information given in Pareek (1984); Das Gupta (1996). Age constraints are from Meert et al. (2013), George and Ray (2017), and McKenzie et al. (2011). WR - whole rock, DZ - detrital zircon. on the western margin of the basin (Fig. 3B). The origin and chronology of this boulder bed remains equivocal and are highly debated in the context of Neoproterozoic global glaciations (Paliwal, 2005). While some researchers believe it to be of glacial origin due to the presence of striation marks on the boulders (Chauhan et al., 2001; Bhatt et al., 2005), others suggest such striation marks could be generated by the erosive action of the windblown sand (Cozzi et al., 2012). Also, there are suggestions that the boulder bed could be locally derived as a part of the overall transgression during the initiation of deposition of the overlying Sonia sandstone formation (Cozzi et al., 2012). Well-developed imbrication at parts of the boulder bed also supports the fluvial origin argument (Cozzi et al., 2012), whereas it is also quite possible that the boulder bed is reworked. The overlying Sonia Formation consists of red and white sandstones and maroon shales believed to have formed in deltaic and beach environment in a marginal marine setting (Chauhan et al., 2004; Sarkar et al., 2008). A dolostone member of a few metres thickness exists near the top of the Sonia Formation (Fig. 3C). This cherty carbonate unit, overlain by the shaly sandstone of Sonia Formation, is exposed at Artiya Kalan, near Jodhpur. The Girbhakar Formation, which forms the topmost part of the Jodhpur Group, is a coarse-grained pebbly sandstone of braided fluvial origin (Chauhan et al., 2004).

Paliwal (1998) first reported the occurrence of $\sim 4 \mathrm{~m}$ thick volcanic-volcaniclastic formation 

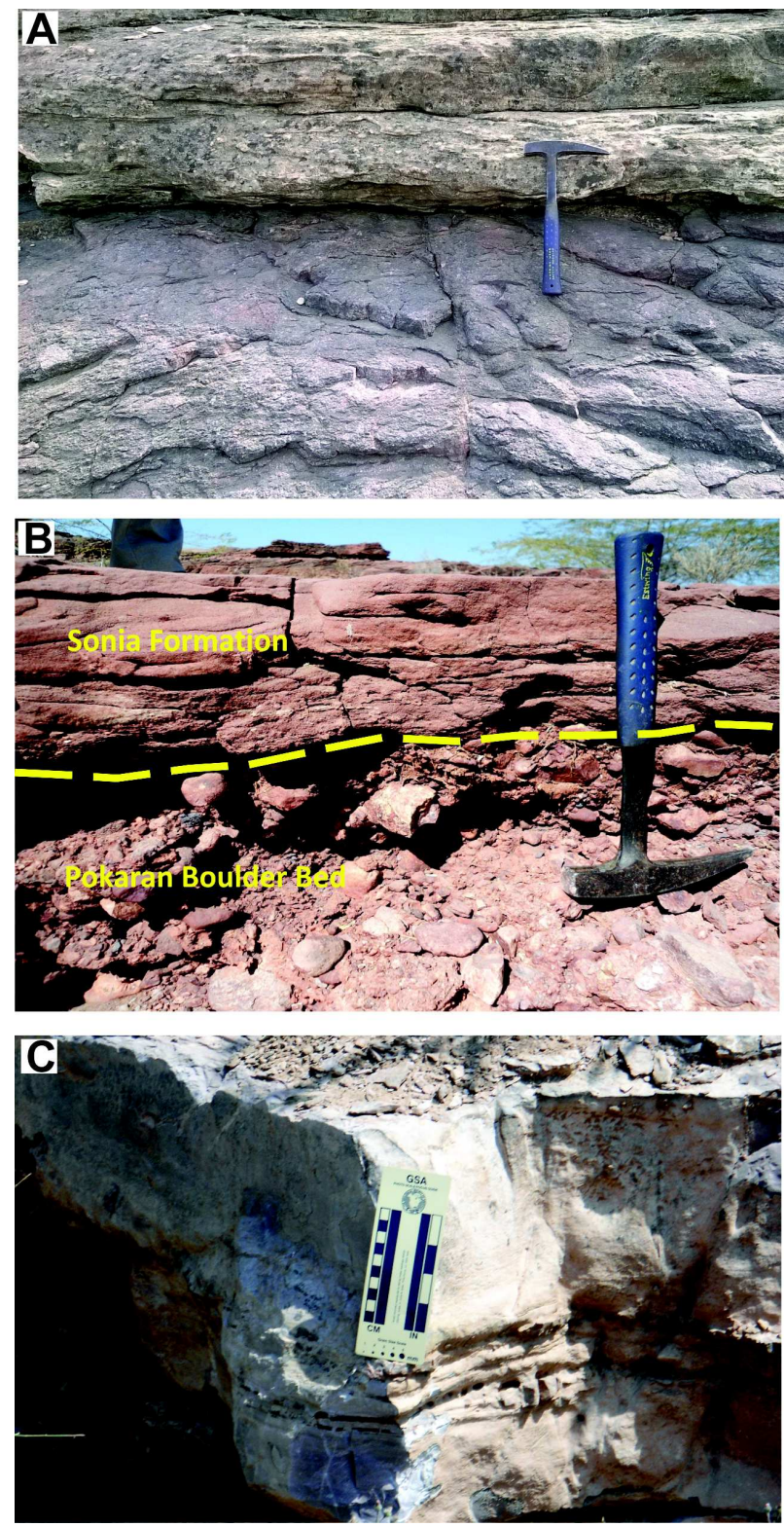

Fig. 3: Field Photographs: Contacts between (A) Malani rhyolite and Sonia Formation at Jodhpur and (B) Pokaran Boulder Bed and shaly sandstone of the Sonia Formation; (C) Dolostone member of the Sonia Formation at Artiya Kalan

made up of rhyolite and calcareous tuff, sandwiched between the Sonia and Girbhakar formations (Fig. 4). The presence of Chhoti Khatu felsic tuff above the basal Sonia Formation suggests that the Marwar Basin had remained volcanically active even after significant amount of sedimentation, well beyond the final phase of Malani volcanism. This formation has so far been reported only at the Chhoti Khatu village near Nagaur on the eastern fringe of the Marwar
Basin. The metasediments of the Sirohi Group form the basement at Chhoti Khatu. The Sonia Formation unconformably overlies the basement, with the unconformity being represented by a polymictic conglomerate horizon. The calcareous tuff which overlies the Sonia Formation, consists of angular fragments of quartz, K-feldspar, randomly oriented blades of biotite and muscovite, minor chert and glass shards. They are embedded in a siliceous-micritic groundmass suggesting a subaqueous deposition for them (Paliwal, 1998).

The marginal marine and fluvial sandstones of the Jodhpur Group are overlain by the shallow marine carbonate rocks of the Bilara Group which forms the middle part of the Marwar Supergroup (Fig. 2). The Bilara Group is divided, from bottom to top, into three formations based on exposures in the southern part of the basin: 1) the Dhanapa Formation which consists of stromatolitic dolostone (Fig. 5A); 2) the Gotan Formation that contains wavy, laminated limestone; and 3) the Pondlo Formation made entirely up of dolostone. In Phalodi, the Dhanapa dolostone formation overlies the Jodhpur Group (Fig. 5A). However, in other parts of the basin, this boundary is marked by chert breccia made up of chert clasts embedded in a fine grained chert matrix (Fig. 5B) indicating a probable depositional hiatus. In the central and northern parts of the Marwar Basin, evaporites are reported from borehole data above the Jodhpur Group. They are classified as Hanseran Evaporite Group (HEG; Das Gupta, 1996). The group comprises cyclic deposits of halite, which forms the most dominant constituent, with associated potash minerals, alternating with laminated anhydrite, clay, dolomite and magnesite. Each of the seven cycles begins with dolomite, anhydrite, minor magnesite and claystone, and ends with layers of halite containing anhydrite, potash minerals, fragments of dolomite, reddish-brown clays and secondary void-filling gypsum (Das Gupta, 1996). These subsurface evaporites are considered to be a facies variation of the Bilara carbonates and are correlated with the contemporaneous evaporite succession, the Ara Group of Oman (Mazumdar and Bhattacharya, 2004; Mazumdar and Strauss, 2006).

The Nagaur Group, which includes the Nagaur and Tunklian formations, unconformably overlies the Bilara Group and forms the youngest succession of the Marwar Supergroup. The initiation of deposition 

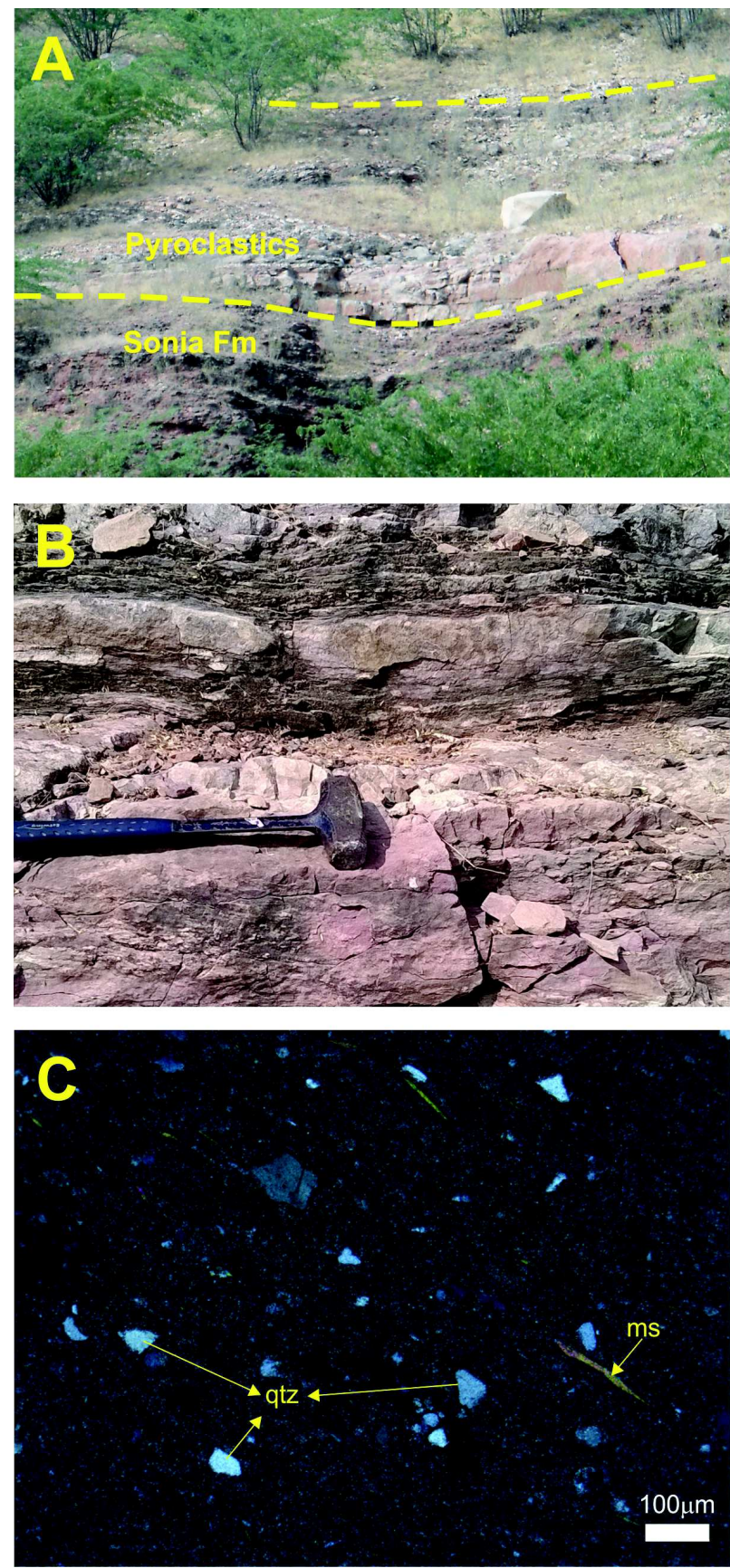

Fig. 4: (A) Outcrop photo of the calcareous tuff at Chhoti Khatu village, Nagaur; (B) A close up outcrop photo of the tuff layer; (C) Photomicrograph of the calcareous tuff showing angular fragments of quartz and blades of mica under cross polarized light

of the Nagaur Group is marked by the Khichan Conglomerate, an assemblage of cobbles and pebbles in a sandy to calcareous matrix. The group comprises fine to coarse grained reddish brown sandstones and siltstones of braided fluvial and marginal marine origin (Singh et al., 2014). They are unconformably overlain
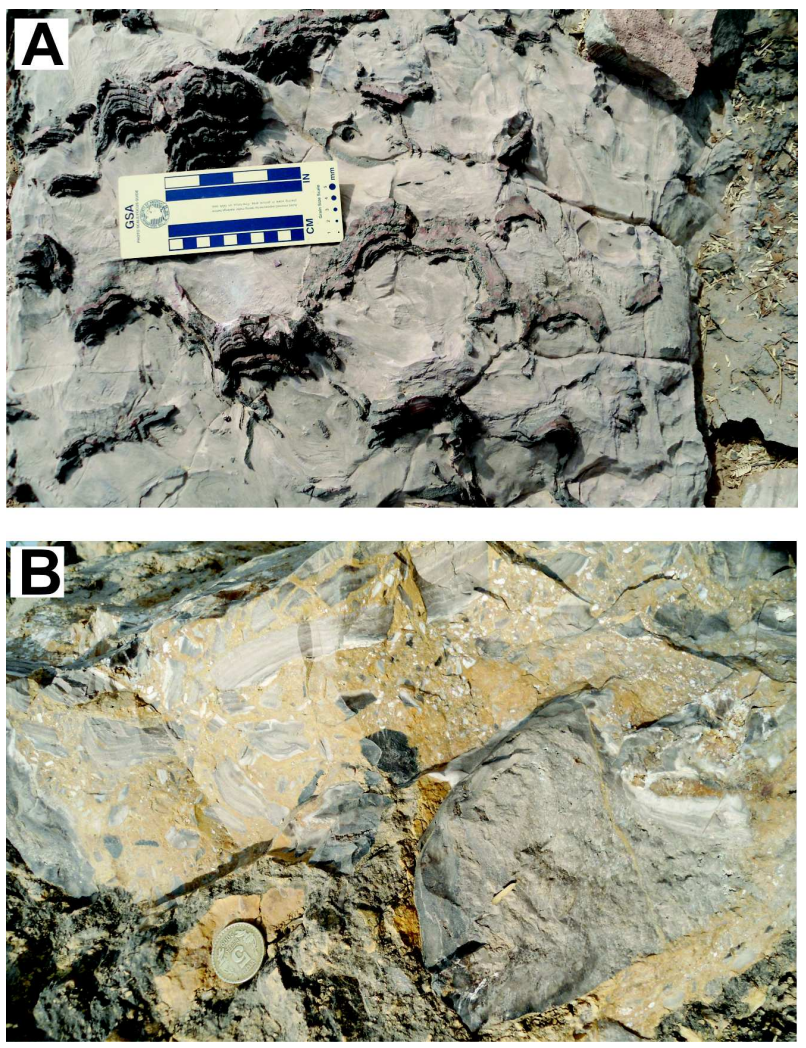

Fig. 5: Field Photographs: (A) Stromatolitic Dhanapa dolostone; (B) Boulders made up of chert clasts within chert matrix overlying the Jodhpur Group

by the Permo-Carboniferous Bap Boulder Bed (Pandey and Bahadur, 2009).

\section{Age of Marwar Supergroup}

\section{Constraints from Biostratigraphy}

Most of our understanding about the age of formation of various units in the Marwar Supergroup is primarily based on biostratigraphy. One of the earliest instances of reported trace fossil discovery was made from the silt layers of the Sonia Formation. Awasthi and Parkash (1981) reported two types of trace fossils: 1) thin, flat, circular objects of $0.5-3 \mathrm{~cm}$ diameter and thickness of about $4 \mathrm{~mm}$, with the flatter side parallel to the bedding plane and marked by a slightly raised rim of $1 \mathrm{~mm}$ high, which resemble the burrows of Laevicyclus; and 2) burrows, that are about $3 \mathrm{~mm}$ in diameter cutting through the bedding and joined along the bedding planes by tracks. Based on the occurrence of similar trace fossils in Salt Range they argued an early Cambrian age for the formation. 
The sedimentary sequence of the Marwar Supergroup had been subjected to intense paleobiological investigations lately following reports of the discovery of medusoidal Ediacaran fossil Marsonia artiyansis from the Sonia Formation (Fig. 6A; Raghav et al., 2005). This was followed by similar reports of Ediacaran fossils Aspidella, Hiemalora, Beltanelliformis minuta (Kumar and Pandey, 2009), exceptionally large-sized Ediacaran discs of a few $\mathrm{mm}$ to $75 \mathrm{~cm}$ diameter and morphologically comparable to Aspidella (Srivastava, 2014), and noncarbonaceous mega plant fossils of Vaucheriacean affinity (Fig. 6B; Kumar et al., 2009) from the middle part of the Jodhpur Group. The latter is, however reinterpreted both as giant benthic seaweeds (Pandey and Sharma, 2016) and as body fossil of algae family incertiesedis (Kumar and Ahmad, 2016). Besides, Kumar et al. (2012) have reported a five armed body fossil morphologically similar to the echinoderms and suggested they could represent a pre-biomineralization stage in the evolution of the echinoids. There were also preliminary reports of the discovery of trace fossils Thalassinoides from the Sonia Formation near Pokaran (Kumar and Ahmad, 2012) and from the Girbhakar Formation (Parihar et al., 2012).

Microbially induced sedimentary structures (MISS) are ubiquitous in the middle part of the Jodhpur Group. The extracellular polymeric substances of the microbial mats make the sand cohesive; binding the sediment grains and produces a wide variety of rather peculiar morphologies (Samanta et al., 2011). There are a number of reports of preservation of such inorganic sedimentary structures (Sarkar et al., 2008; Samanta et al., 2015). Kumar and Ahmad, (2014) classified MISS into three categories: 1) structures that can be compared with inorganically formed sedimentary structures like flat laminated beds, wrinkle marks, cracks, buns, mounds and discs, 2) structures that could not be produced by inorganic processes alone which included Aristophycus, Arumberia banski, Rameshia rampurensis and Jodhpuria circularis, and 3) structures without any specific morphology. These fossil assemblages suggested an Ediacaran age for the Jodhpur Group.

The chert associated with the Gotan limestone formation of the Bilara Group had preserved palynofossil assemblage made up of eight taxa of acritarchs with characteristic features of Sphaero
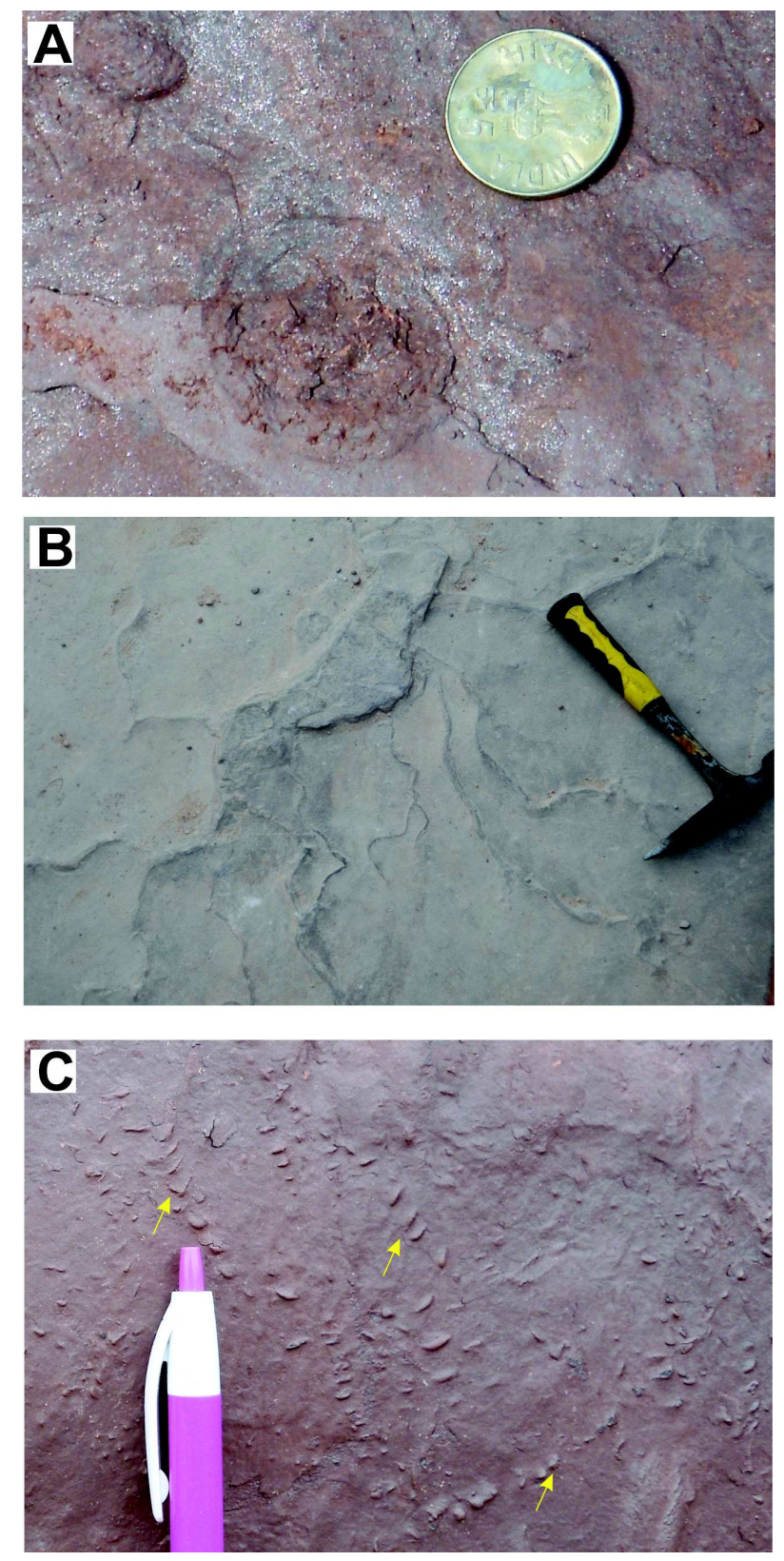

Fig. 6: Field photographs: (A) Ediacaran-type medusoid Marsonia artiyansis from the type locality Artiya Kalan; (B) Megaplant/benthic seaweeds/incertiesedis from the Sonia sandstone formation; (C) Diplichnites from the Nagaur sandstone formation at Dulmera

morphida, Sphaerohystrichomorphida and Versi morphida subgroups, four taxa of cyanobacteria which show unbranched trichomes with a coccoidal form, and one bio-mineralized tube comparable to modern families Croococcaseae, Nostocaseae and Oscillatoriaceae (Babu et al., 2009). Another acritarch assemblage of Asteridium, Dictyotidium birvetense, Pterospermella solida and Annulum 
squamaceum from the lower part of the Bilara Group suggest a late Ediacaran to early Cambrian age for the middle Marwar Supergroup. Similarly, the Hanseran Evaporite Group is marked by an abundance of acritarchs represented by Retisphaeridium dichamerum, Dichtyotidium birvetense, Cristallinum cambriense, Comasphaeridium and Archaeodiscina umbonulata, suggesting an early to middle Cambrian age for the formation (Prasad et al., 2010).

A number of well-preserved trace fossil assemblages including Rusophycus disymus, Chondrites, Cruziana, Dimorphichnus obliquus, Monomorphichnus monolinearis, Diplichnites (Fig. 6C), Skolithos, Palaeophycus tubalaris, Planolites, Gyrophyllites, Lockeia, Merostomichnites, and Psammichnites (Kumar and Pandey, 2010; Pandey et al., 2014) were reported from the Nagaur Group. Also, there were reports of index fossil Treptichnus pedum (Srivastava, 2012; Pandey et al., 2014; Singh et al., 2014; Sharma et al., 2018) and body fossil of suspected arthropod redlichid trilobite (Singh et al., 2013) supporting Cambrian age for the deposition of the upper Marwars.

\section{Constraints from Chemostratigraphy}

Most of the chemostratigraphic efforts to constrain the age of the Supergroup were attempted in the Gotan limestone formation of the Bilara Group. Two separate efforts (Mazumdar and Strauss, 2006; George and Ray, 2017) to constrain the age of Bilara Group using Sr isotope stratigraphy have yielded lowest ${ }^{87} \mathrm{Sr} /{ }^{86} \mathrm{Sr}$ of 0.7082 and 0.7081 , respectively, for the Gotan Formation. These results suggested a late Edicaran depositional age of $\sim 570 \mathrm{Ma}$ for the Bilara Group corroborating the biostratigraphy.

Carbon isotope stratigraphy had been widely used as a potent tool for making both intra and interbasinal correlations, as well as to better understand the ocean chemistry during the terminal Proterozoic (Halverson and Shields-Zhou, 2011). The period is marked by large scale negative and positive excursions in $\delta^{13} \mathrm{C}$ of the marine carbonates in association with the global glaciations - 'the Snowball Earth' events (Hoffman et al., 1998). Similar negative $\delta^{13} \mathrm{C}$ excursions were also reported during the $\sim 580$ Ma Gaskiers glaciation, and the Shuram anomaly, with the $\delta^{13} \mathrm{C}$ going down up to $-12 \%$ o during the latter (Le
Guerroue, 2006). Due to its terminal Proterozoic depositional age and proximity to the continents from which these events are reported (Davis et al., 2014), the Bilara Group had been subjected to a number of ${ }^{13} \mathrm{C}$ isotope stratigraphy investigations. Overall, the reported $\delta^{13} \mathrm{C}$ values range from -10.3 to $2.4 \%$ for the bottom most Dhanapa dolostone formation and -1.9 to $-0.6 \%$ for the topmost Pondlo Dolostone.The bulk of the Bilara Group is comprised of the middle Gotan limestone formation which has $\delta^{13} \mathrm{C}$ varying from -10.7 to $+4.7 \%$ (Pandit et al., 2001; Maheshwari et al., 2003; Mazumdar and Bhattacharya, 2004; Ansari et al., 2018). Some of the very low $\delta^{13} \mathrm{C}$ values reported in both the Dhanapa and Gotan Formations could be potential candidates for the Shuram anomaly (Ansari et al., 2018) in the wake of the $\sim 570$ Ma age suggested by Sr isotope stratigraphy; however, further chemostratigraphic and geochronological constraints are required to ascertain the case.

Mazumdar and Bhattacharya (2004) have carried out $\delta^{13} \mathrm{C}$ measurements in the Bilara Group $\left(\delta^{13} \mathrm{C}=-8\right.$ to $+4 \%$ ) and found their $\delta^{13} \mathrm{C}$ pattern comparable with that of the Hanseran Evaporite Group $\left(\delta^{13} \mathrm{C}=-8\right.$ to $+2 \%$; Banerjee et al., 1998). Similarly, both the units have comparable $\delta^{34} \mathrm{~S}$ (average $\delta^{34} \mathrm{~S} \sim 33 \%$ ) measured in sulphates, and ${ }^{87} \mathrm{Sr} /{ }^{86} \mathrm{Sr}$ (lowest ${ }^{87} \mathrm{Sr} /{ }^{86} \mathrm{Sr}=0.7081$ ), suggesting that they are coeval and the Hanseran Group is a homotaxial facies variant of the Bilara Group (Mazumdar and Strauss, 2006). These chemostratigraphic constraints correlate the Bilara Group with a host of Ediacaran-early Cambrian carbonate deposits such as the Nafun and Ara Groups of Oman, Salt Range Formation of the Pakistan, Krol Group of the Lesser Himalaya, and Doushantuo Formation of the South China (Fig. 7).

\section{Constraints from Radioisotope Data}

The lower time bound for the initiation of sedimentation in the Marwar Supergroup is given by the $752 \pm 18$ $\mathrm{Ma}(\mathrm{Pb}-\mathrm{Pb}$ zircon) age obtained for the terminal dyke phase of Malani magmatism (Fig. 2; Meert et al., 2013). Though, a late Neoproterozoic-early Cambrian deposition period was suggested traditionally for the Marwars (Pandit et al., 2001), there were hardly any radiometric age data available from the Supergroup to corroborate it until recently. It was generally perceived that the sedimentation in the Marwar Basin 


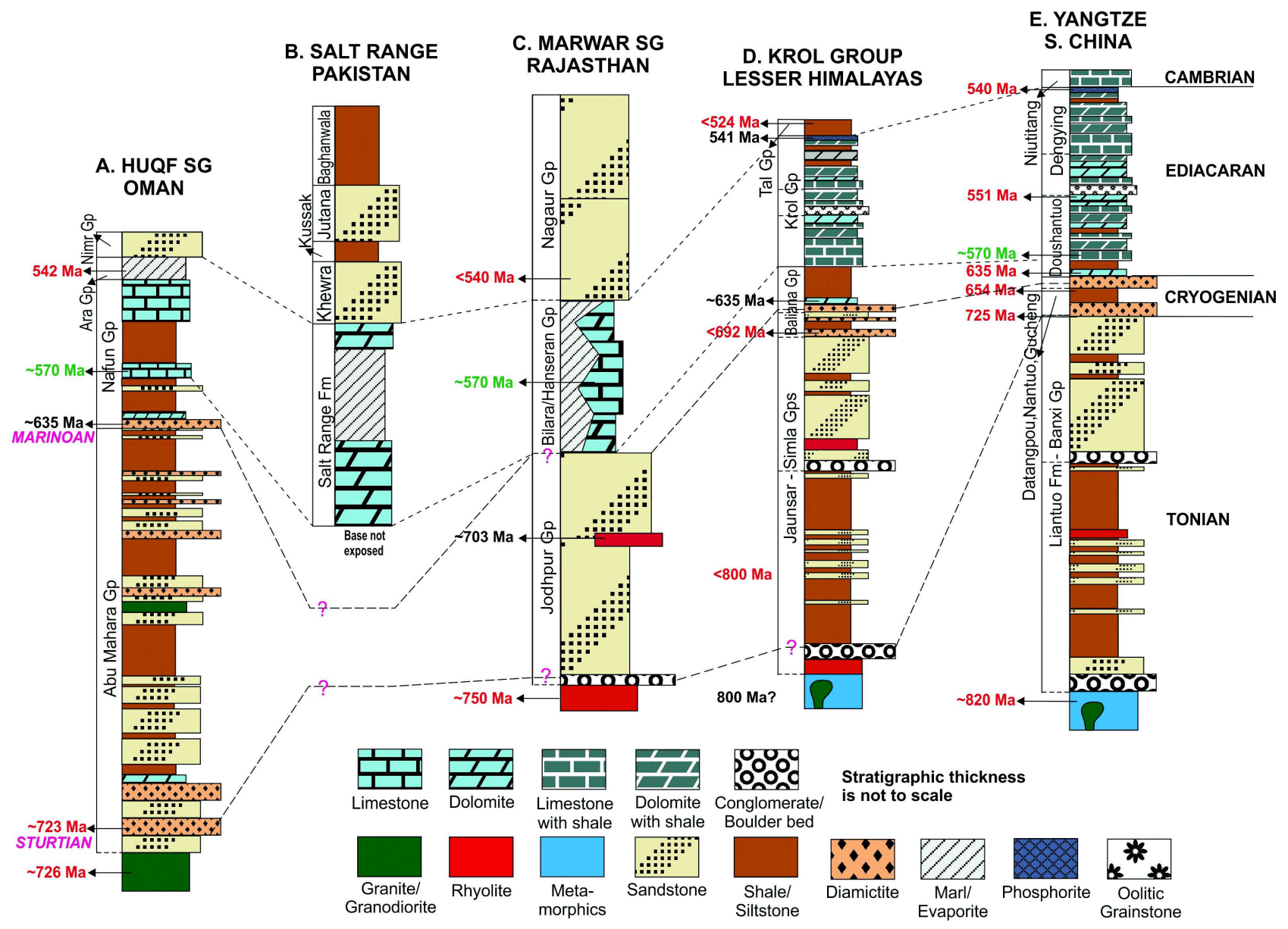

Fig. 7: Comparative stratigraphy and proposed correlations between the Marwar Supergroup, Rajasthan, the Huqf Supergroup of Oman, the Salt Range of Pakistan, the Lesser Himalayas of India, and the Yangtze platform sequences of South China, respectively. Correlations are made mostly based on the available age data, similarity in detrital zircon distribution and paleogeography of the basins during the late Neoproterozoic-early Cambrian period. The ages marked in red are based on $\mathrm{U}-\mathrm{Pb}$ zircon, and green are based on ${ }^{87} \mathrm{Sr} /{ }^{86} \mathrm{Sr}$ isotope stratigraphy. All other radiometric ages are given in black. Data sources: Marwar Supergroup - (McKenzie et al., 2011; Meert et al., 2013; Davis et al., 2014; George and Ray, 2017); Huqf Supergroup - (Kilner et al., 2005; Le Guerroue, 2006; Rieu et al., 2007 and the references therein); Lesser Himalaya - (Jiang et al., 2003; Klootwijk, 1979; McKenzie et al., 2011; Tripathy and Singh, 2011 and the references therein). Yangtze block, South China - (Jiang et al., 2003, 2007, 2011; Macouin et al., 2004; Wang et al., 2012 and the references therein). Salt Range - (Krishnan, 1966; McElhinny, 1970; Gee, 1989)

got initiated in the late Ediacaran period, $\sim 115 \mathrm{Ma}$ after the Malani magmatism. The lack of physical evidence for either of the Neoproterozoic 'snowball Earth' events in the basin was often cited as the rationale behind this argument (Davis et al., 2014; Turner et al., 2014). However, a felsic tuff located near the Chhoti Khatu village in the eastern flank of the Marwar Basin had been dated to $703 \pm 40$ Ma using $\mathrm{Rb}-\mathrm{Sr}$ whole rock isochron method recently (George and Ray, 2017). The new age information from the tuff, which is sandwiched between the Sonia and Girbhakar formations, shows that the sedimentation in the Marwar Supergroup began very much during the Cryogenian period, and that the apparent hiatus between the Malani volcanism and the initiation of deposition of the Marwar Supergroup may not have been protracted as thought before.

There were attempts to constrain the maximum age of deposition of various formations in the Marwar Supergroup using $\mathrm{U}-\mathrm{Pb}$ dating of detrital zircons. The detrital zircon age data from the Jodhpur Group show major peaks at $\sim 750 \mathrm{Ma}, \sim 850 \mathrm{Ma}$, and $\sim 1.8 \mathrm{Ga}$ suggesting a maximum depositional age of $\sim 750 \mathrm{Ma}$ 
for the Jodhpur Group. The first two ages are more likely the ages of the basements, MIS and Erinpura Granites, respectively, while the zircons of $\sim 1.8 \mathrm{Ga}$ age peak could be derived from either BGC-II or the granites located in the northern part of the Delhi Supergroup (Malone et al., 2008; Turner et al., 2014). McKenzie et al. (2011) carried out detrital zircon analyses of the Nagaur Formation and reported youngest zircon ages of $\sim 540 \mathrm{Ma}$. This can be considered as the maximum depositional age of the Nagaur Formation and is well in agreement with the biostratigraphy.

\section{Sediment Provenance}

The paleocurrent analyses (Awasthi and Parkash, 1981; Chauhan et al., 2001; Chauhan et al., 2004) in the Sonia and Girbhakar formations suggest paleoflow directions from west-southwest, implying majority of the sediment sources could be located along the eastern fringes of the basin. The U-Pb detrital zircon analyses of the Marwar siliciclastics have shown two major age peaks $-0.7-0.9 \mathrm{Ga}$ and $\sim 1.8 \mathrm{Ga}$, and a minor peak at $2.5 \mathrm{Ga}$, indicating majority of the sediments were sourced from Erinpura Granite and/or MIS, and BGC-2 and/or Delhi Supergroup granites, respectively, with minor input from the basement BGC-1 (Malone et al., 2008; Turner et al., 2014). It was also suggested that the source of $\sim 1.8 \mathrm{Ga}$ zircons, either BGC-2 and/or Delhi Supergroup, acted as a common sediment source/s for both Marwar and the Vindhyan basins during their evolution (Turner et al., 2014). Similarly, George and Ray (2017) carried out quantitative provenance analysis of the Marwar siliciclastics using rare earth elements and neodymium isotopes, and have suggested a combined source of Delhi Supergroup and BGC-2 contributing sediments to the Jodhpur Group. Also, the Delhi Supergroup and/ or Erinpura Granites supplied sediments to the subsequently formed Bilara and Nagaur Groups while the sediment supply from the BGC-2 got truncated. They suggested a hiatus of $\sim 100$ Ma between the deposition of lower and the middle Marwars based on the available geochronologic and chemostrati

\section{References}

Ansari A H, Pandey S K, Sharma M, Agrawal S and Kumar Y (2018) Carbon and oxygen isotope stratigraphy of the Ediacaran Bilara Group, Marwar Supergroup, India: graphic constraints as well as the sharp change in provenance, and speculated that this break in deposition could likely be the reason for the absence of any evidence for the 'snowball Earth' events in the Marwar Basin.

\section{Looking to the Future}

Although, a large number of studies have been carried out in the Marwar Basin in the last decade, there are a few areas which might require some rethinking. In light of the new radiometric age data from the Jodhpur Group, the trace fossil discoveries from the Sonia Formation may be viewed in a new perspective. Some of the reported trace fossils which closely resemble the Ediacaran fauna may actually be precursors to them. Multiple chemostratigraphic studies in the Bilara carbonates have reported $\delta^{13} \mathrm{C}$ negative excursions of varying magnitude. Although they provided valuable data for inter and intra-basinal correlations, none of these excursions could be correlated to any of the Neoproterozoic global events (Fig. 7), apart from the suspected Shuram anomaly reported by Ansari et al. (2018). The position of the Pc-C boundary remains ambiguous in the Marwar Supergroup. The rich fossil assemblage and the reported presence of index fossil Treptichnus pedum suggest early Cambrian antiquity for the Nagaur Group; however, there is no evidence yet to suggest that the boundary lies in the underlying Pondlo or Gotan formations. Constraining ages of the sedimentary sequences in Precambrian terrain are often hard for want of biostratigraphic records. Lack of volcanics or volcaniclastics in the sequences make the task harder, which is the case with MarwarSupergroup. It is high time for more focussed geochronologic efforts within the supergroup to better constrain its time frames of deposition.

\section{Acknowledgements}

BGG thanks Linto Alappat for inviting to contribute to this special issue. The manuscript has benefitted considerably by the comments of D K Pandey, S Patranabis-Deb, Iftikhar Ahmad and two anonymous reviewers.

Evidence for high amplitude carbon isotopic negative excursions Precambrian Res 308 75-91

Awasthi A K and Parkash B (1981) Depositional environments of unfossiliferous sediments of the Jodhpur Group, western 
India Sediment Geol 30 15-42

Babu R, Singh V K and Shukla M (2009) Cryptic bioentities with their significance from the Gotan Formation of Bilara Group, Marwar Supergroup, Rajasthan Curr Sci 96 15751577

Bhatt D K, Prasad S, Jain R L and Mathur A K (2005) Some Critical Field Observations on the Genesis and Stratigraphical Status of Pokaran Boulder Bed, Western Rajasthan J Geol Soc India 65 301-308

Canfield D E, Poulton S W and Narbonne G M (2007) LateNeoproterozoic Deep-Ocean Oxygenation and the Rise of Animal Life Science 315 92-95

Chauhan D S, Mathur K M and Ram N (2001) Geological nature of the Pokaran boulder bed: Paleoenvironmental, paleoclimatic and stratigraphic implications $J$ Geol Soc India 58 425-433

Chauhan D S, Ram B and Ram N (2004) Jodhpur sandstone: A gift of ancient beaches to western Rajasthan J Geol Soc India 64 265-276

Collins A S and Pisarevsky S A (2005) Amalgamating eastern Gondwana: The evolution of the Circum-Indian Orogens Earth-Science Rev 71 229-270

Cozzi A, Rea G and Craig J (2012) From global geology to hydrocarbon exploration: Ediacaran-Early Cambrian petroleum plays of India, Pakistan and Oman Geol Soc London Spec Publ 366 131-162

Davis J K, Meert J G and Pandit M K (2014) Paleomagnetic analysis of the Marwar Supergroup, Rajasthan, India and proposed interbasinal correlations J Asian Earth Sci 91 339-351

Gee E R (1989) Overview of the geology and structure of the Salt Range, with observations on related areas of northern Pakistan. ed. D G Gee Spec Pap Geol Soc Am 232 95-112

George B G and Ray J S (2017) Provenance of sediments in the Marwar Supergroup, Rajasthan, India: Implications for basin evolution and Neoproterozoic global events $J$ Asian Earth Sci 147 254-270

Gregory L C, Meert J G, Bingen B, Pandit M K and Torsvik T H (2009) Paleomagnetism and geochronology of the Malani Igneous Suite, Northwest India: Implications for the configuration of Rodinia and the assembly of Gondwana Precambrian Res 170 13-26

Le Guerroue E (2006) Sedimentology and Chemostratigraphy of the Ediacaran Shuram Formation, Nafun Group, Oman. PhD Thesis, Swiss Federal Institute of Technology, Zurich (ETHZ)

Das Gupta S P (1996) Marwar Supergroup Evaporites, Rajasthan ed. A. Bhattacharya Mem Geol Soc India 49-58

Halverson G P and Shields-Zhou G (2011) Chemostratigraphy and the Neoproterozoic glaciations. In The Geological Record of Neoproterozoic Glaciations (eds. E Arnaud, G Halverson and G Shields-Zhou) Geol Soc London Mem pp 51-66

Heron A M (1932) The Vindhyans of Western Rajputana Rec Geol Surv India 65 457-489

Hoffman P F, Kaufman A J, Halverson G P and Schrag D P (1998) A Neoproterozoic Snowball Earth Science 281 $1342-1346$

Jiang G, Kaufman A J, Christie-Blick N, Zhang S and Wu H (2007) Carbon isotope variability across the Ediacaran Yangtze platform in South China: Implications for a large surface-to-deep ocean $\mathrm{d}^{13} \mathrm{C}$ gradient Earth Planet Sci Lett $261303-320$

Jiang G, Shi X, Zhang S, Wang Y and Xiao S (2011) Stratigraphy and paleogeography of the Ediacaran Doushantuo Formation (ca. 635-551Ma) in South China Gondwana Res 19 831-849

Jiang G, Sohl L E and Christie-Blick N (2003) Neoproterozoic stratigraphic comparison of the Lesser Himalaya (India) and Yangtze block (south China): Paleogeographic implications Geology 31 917-920

Kilner B, Mac Niocaill C and Brasier M (2005) Low-latitude glaciation in the Neoproterozoic of Oman Geology 33 413416

Klootwijk C T (1979) A review of palaeomagnetic data from the Indo-Pakistani fragment of Gondwanaland. In Geodynamics of Pakistan (eds. A Farah and K A DeJong) Geol Surv Pakistan, Quetta pp 41-80

Krishnan M S (1966) Salt Tectonics in the Punjab Salt Range, Pakistan Geol Soc Am Bull 77 115-122

Kumar S and Ahmad S (2012) Discovery of thalassinoides burrows in the Ediacaran Jodhpur Sandstone (=Pokaran Sandstone), Marwar supergroup, Pokaran Area, Western Rajasthan $J$ Palaeontol Soc India 57 159-162

Kumar S and Ahmad S (2014) Microbially induced sedimentary structures (MISS) from the Ediacaran Jodhpur Sandstone, Marwar Supergroup, western Rajasthan J Asian Earth Sci $91352-361$

Kumar S and Ahmad S (2016) Problematic structures from the ediacaran Jodhpur sandstone, Rajasthan, India and their possible affinity J Palaeontol Soc India 61 63-73

Kumar S, Misra P K and Pandey S K (2009) Ediacaran megaplant fossils with Vaucheriacean affinity from the Jodhpur Sandstone, Marwar Supergroup, western Rajasthan Curr 
Sci 97 701-705

Kumar S and Pandey S K (2009) Note on the occurrence of Arumberia banksi and associated fossils from the Jodhpur sandstone, Marwar Supergroup, western Rajasthan $J$ Palaeontol Soc India 54 171-178

Kumar S and Pandey S K (2010) Trace fossils from the Nagaur Sandstone, Marwar Supergroup, Dulmera area, Bikaner district, Rajasthan, India $J$ Asian Earth Sci 38 77-85

Kumar S, Srivastava D K and Ahmad S (2012) Five-armed body fossil from the Ediacaran Jodhpur Sandstone, Marwar Supergroup, western Rajasthan, India: A possible precursor of phylum Echinodermata Curr Sci 102 24-26

Kumar V (1999) Evolution and geological set-up of the NagaurGanganagar Basin, northwestern Rajasthan. In Geological evolution of northwestern India (ed. B S Paliwal) Scientific Publishers, India, Jodhpur pp 34-60

Linnemann U and Sharma M (2014) U-Pb LA-ICP-MS zircon ages from the Marwar Supergroup and its underlying basement. In International Field Workshop on the Marwar Supergroup, Rajasthan, India (eds. M Sharma, S K Pandey and S Kumar) The Society of Earth Scientists, India. pp. 76

Macouin M, Besse J, Ader M, Gilder S, Yang Z, Sun Z and Agrinier P (2004) Combined paleomagnetic and isotopic data from the Doushantuo carbonates, South China: Implications for the "snowball Earth" hypothesis Earth Planet Sci Lett 224 387-398

Maheshwari A, Sial A N and Mathur S C (2003) Carbon and oxygen isotope profiles from the terminal precambrian Marwar Supergroup, Rajasthan, India Carbonates and Evaporites 18 10-18

Malone S J, Meert J G, Banerjee D M, Pandit M K, Tamrat E, Kamenov G D, Pradhan V R and Sohl L E (2008) Paleomagnetism and Detrital Zircon Geochronology of the Upper Vindhyan Sequence, Son Valley and Rajasthan, India: A ca. 1000Ma Closure age for the Purana Basins? Precambrian Res 164 137-159

Mazumdar A and Bhattacharya S K (2004) Stable isotopic study of late Neoproterozoic-early Cambrian (?) sediments from Naguar-Ganganagar basin, western India: Possible signatures of global and regional C-isotopic events Geochem J38 163-175

Mazumdar A and Strauss H (2006) Sulfur and strontium isotopic compositions of carbonate and evaporite rocks from the late Neoproterozoic-early Cambrian Bilara Group (NagaurGanganagar Basin, India): Constraints on intrabasinal correlation and global sulfur cycle Precambrian Res 149 217-230
McElhinny M W (1970) Palaeomagnetism of the cambrian purple sandstone from the Salt Range, west Pakistan Earth Planet Sci Lett 8 149-156

McFadden K A, Huang J, Chu X, Jiang G, Kaufman A J, Zhou C, Yuan X and Xiao S (2008) Pulsed oxidation and biological evolution in the Ediacaran Doushantuo Formation Proc Natl Acad Sci USA 105 3197-202

McKenzie N R, Hughes N C, Myrow P M, Xiao S and Sharma M (2011) Correlation of Precambrian-Cambrian sedimentary successions across northern India and the utility of isotopic signatures of Himalayan lithotectonic zones Earth Planet Sci Lett 312 471-483

Meert J G (2003) A synopsis of events related to the assembly of the eastern Gondwana Tectonophysics 362 1-40

Meert J G, Pandit M K and Kamenov G D (2013) Further geochronological and paleomagnetic constraints on Malani (and pre-Malani) magmatism in NW India Tectonophysics 608 1254-1267

Och L M and Shields-Zhou G A (2012) The Neoproterozoic oxygenation event: Environmental perturbations and biogeochemical cycling Earth-Science Rev 110 26-57

Paliwal B S (2005) Discussion on Critical field observations on the genesis and stratigraphical status of Pokaran boulder bed, western Rajasthan J Geol Soc India 66 373-376

Paliwal B S (1998) Felsic volvanics interlayered with sediments of the Marwar Supergroup of Chhoti Khatu, District Nagaur, Rajasthan J Geol Soc India 52 81-86

Pandey D K and Bahadur T (2009) A review of the stratigraphy of Marwar Supergroup of west-central Rajasthan $J$ Geol Soc India 73 747-758

Pandey D K, Uchman A, Kumar V and Shekhawat R S (2014) Cambrian trace fossils of the Cruziana ichnofacies from the Bikaner-Nagaur Basin, north western Indian Craton $J$ Asian Earth Sci 81 129-141

Pandey S K and Sharma M(2016) Enigmatic Ediacaran megascopic bedding plane structures on the Sonia Sandstone, Jodhpur Group, Marwar Supergroup, India: seaweed or problematica? Geol J 50 414-433

Pandit M K, Sial AN, Jamrani S S and Ferreira V P (2001) Carbon Isotopic Profile Across the Bilara Group Rocks of TransAravalli Marwar Supergroup in Western India: Implications for Neoproterozoic - Cambrian Transition Gondwana Res 4 387-394

Pareek H S (1981) Basin configuration and sedimentary stratigraphy of western Rajasthan J Geol Soc India 22 $517-527$

Pareek H S (1984) Pre-Quaternary geology and mineral resources 
of northwestern Rajasthan Mem Geol Soc India $\mathbf{1 1 5}$

Parihar V S, Gaur V and Nama S L (2012) Trace Fossils and Microbial Mat- Induced Sedimentary Structures from the Girbhakar Sandstone of Marwar Supergroup, Bhopalgarh Area, Jodhpur, Rajasthan, India J Earth Sci Clim Changes 12-2 1-3

Prasad B, Asher R and Borgohai B (2010) Late Neoproterozoic (Ediacaran)-Early Paleozoic (Cambrian) acritarchs from the marwar supergroup, Bikaner-Nagaur Basin, Rajasthan $J$ Geol Soc India 75 415-421

Raghav K S, De C and Jain R L (2005) The first record of Vendian Medusoids and trace fossil-bearing algal matgrounds from the basal part of the Marwar Supergroup of Rajasthan, India Indian Miner 59 23-30

Rieu R, Allen P A, Cozzi A, Kosler J and Bussy F (2007) A composite stratigraphy for the Neoproterozoic Huqf Supergroup of Oman: Integrating new litho-, chemo- and chronostratigraphic data of the Mirbat area, southern Oman J Geol Soc London 164 997-1009

Roy A B (2001) Neoproterozoic Crustal Evolution of Northwestern Indian Shield: Implications on Break up and Assembly of Supercontinents Gondwana Res 4 289306

Roy A B and Jakhar S R (2002) Geology of Rajasthan (Northwest India)/: Precambrian to recent, Scientific Publishers, India. pp. 421

Samanta P, Mukhopadhyay S, Mondal A and Sarkar S (2011) Microbial mat structures in profile: The Neoproterozoic Sonia Sandstone, Rajasthan, India J Asian Earth Sci $\mathbf{4 0}$ 542-549

Samanta P, Mukhopadhyay S, Sarkar S and Eriksson P G (2015) Neoproterozoic substrate condition vis-a-vis microbial mat structure and its implications: Sonia Sandstone, Rajasthan, India J Asian Earth Sci 106 186-196

Sarkar S, Bose P, Samanta P, Sengupta P and Eriksson P (2008) Microbial mat mediated structures in the Ediacaran Sonia
Sandstone, Rajasthan, India, and their implications for proterozoic sedimentation Precambrian Res 162 248-263

Sharma M, Ahmad S, Pandey S K and Kumar K (2018) On the ichnofossil Treptichnus pedum: inferences from the Nagaur Sandstone, Marwar Supergroup, India Bull Geosci 93 121

Singh B P, Bhargava O N, Chaubey R S and Kishore N (2014) Ichnology and Depositional Environment of the Cambrian Nagaur Sandstone (Nagaur Group) Along the Dulmera Section, Bikaner-Nagaur Basin, Rajasthan Acta Geol Sin 88 1665-1680

Singh B P, Bhargava O N, Kishore N, Ahliwalia A H and Chaubey R S (2013) Arthropod from the Bikaner - Nagaur Basin, Peninsular India Curr Sci 104 706-707

Srivastava P (2014) Largest Ediacaran discs from the Jodhpur Sandstone, Marwar Supergroup, India: Their palaeobiological significance Geosci Front 5 183-191

Srivastava P (2012) Treptichnus pedum: An Ichnofossil representing Ediacaran - Cambrian boundary in the Nagaur Group, the Marwar Supergroup, Rajasthan, India Proc Indian Natl Sci Acad 78 161-169

Tripathy G R and Singh S K (2011) Re-Os isotopes and redoxsensitive elements of the Himalayan black shales: Implications to marine anoxia near the Pc-C boundary Mineral Mag 752031

Turner C C, Meert J G, Pandit M K and Kamenov G D (2014) A detrital zircon $\mathrm{U}-\mathrm{Pb}$ and $\mathrm{Hf}$ isotopic transect across the Son Valley sector of the Vindhyan Basin, India: Implications for basin evolution and paleogeography Gondwana Res 26 348-364

Wang X, Shi X, Jiang G and Zhang W (2012) New U-Pb age from the basal Niutitang Formation in South China: Implications for diachronous development and condensation of stratigraphic units across the Yangtze platform at the Ediacaran-Cambrian transition J Asian Earth Sci 48 1-8. 